\title{
Correlates of Technological Gap in Turmeric Production Technology by the Farmers of West Jaintia Hills District, Meghalaya, India
}

\author{
Phidalangki Lyngdoh*, M. Kunjaraj Singh, Daya Ram and N. Gopimohan Singh \\ College of Agriculture, Central Agricultural University Imphal-795004 Manipur (India) \\ *Corresponding author
}

\begin{tabular}{|c|c|}
\hline & A B S T R A C T \\
\hline $\begin{array}{l}\text { K e y w o r d s } \\
\text { Technological gap, } \\
\text { Turmeric, turmeric } \\
\text { growers, Meghalaya }\end{array}$ & \multirow{3}{*}{$\begin{array}{l}\text { The present study was conducted during the year 2018-19 in West Jaintia Hills District, } \\
\text { Meghalaya. Out of total eleven districts in the state, West Jaintia Hills District was } \\
\text { selected as this district has the highest area under turmeric cultivation. Laskein block and } \\
\text { Thadlaskein block of West Jaintia Hills District were purposively selected for the study } \\
\text { and multistage sampling procedure was followed. Turmeric growers were randomly } \\
\text { selected from six villages by using stratified random sampling with proportional allocation } \\
\text { method making a total sample of } 120 \text { respondents for the study. Correlation analysis } \\
\text { between technological gap and characteristics of the turmeric growers revealed that } \\
\text { variables such as annual income, mass media exposure and risk orientation were } \\
\text { negatively significant with technological gap at } 0.05 \text { level of significance. Education, } \\
\text { extension contact, economic motivation and innovation proneness were negatively } \\
\text { significant with technological gap of the turmeric growers at } 0.01 \text { level of significance. }\end{array}$} \\
\hline Article Info & \\
\hline $\begin{array}{l}\text { Accepted: } \\
\text { 17 April } 2019 \\
\text { Available Online: } \\
10 \text { May } 2019\end{array}$ & \\
\hline
\end{tabular}

\section{Introduction}

Turmeric is an ancient spice native to South East Asia and India. It is also known as "Golden spice of India" and widely used as a spice and preservative in culinary industries, a colouring agent in textile. The presence of cucurmin, a substance with powerful antiinflammatory and antioxidant properties renders a number of medicinal properties. The rhizomes are used to treat stomach and liver ailments, arthritic, muscular disorders, biliary disorders, anorexia, cough, diabetic wounds, rheumatism and sinusitis in traditional medicine. It also has promising pharmaceutical activity against cancer, dermatitis, Acquired Immune Deficiency Syndrome (AIDS), inflammation, high cholesterol levels, and dyspeptic conditions.

A large proportion of the population in India is rural based and depends on agriculture for a living. There is a need for enhanced and stable growth of the agriculture sector as it plays an important role in generating purchasing power among the rural population by creating on-farm and off-farm employment opportunities. Majority of the marginal and small farmers could not sustain from agricultural income alone so it is important for these farmers to supplement income from other economic activities. Therefore, different 
technologies and activities for improved agricultural practices should be designed to address the vulnerabilities of the rural poor for increasing productivity, efficiency and income.

\section{Materials and Methods}

The present study was conducted in West Jaintia Hills District, Meghalaya by using Expost facto research design. Multistage sampling procedure was followed for selection of district, sub-division, villages and respondents. Of the eleven districts, West Jaintia Hills District was purposively selected as this district has the highest area under turmeric cultivation. West Jaintia Hills District comprise of three Community \& Rural Development (C\&RD) blocks, of which two blocks i.e. Laskein and Thadlaskein blocks were purposively selected for the study. Further, three villages were selected randomly from each block and the list of turmeric growers from each selected villages of the two blocks were obtained from the District Agriculture Office. Turmeric growers were selected from all the six villages by using stratified random sampling with proportional allocation method making a total sample of 120 respondents for the study. The data were collected through structured interview schedule. The exploratory and analytical research design adopted for this study and the data were analyzed by using appropriate statistical methods.

\section{Results and Discussion}

Table- 1 reveals the frequency and percentage of respondents having different levels of gap, namely full gap, partial gap and nilgap for the recommended package of practices in turmeric cultivation for each practice.

Out of the total 120 respondents, it was observed that majority of the respondents showed full gap in case of disease management (89.17\%), application of fertilizers $(66.67 \%)$, pest management $(65.83 \%)$ and seed treatment $(49.17 \%)$. Whereas, cent per cent of the respondents showed nil gap in case of practice such as planting time and harvesting time. Further, majority of the respondents showed partial gap in other practices like processing (79.17\%), application of FYM (78.33\%), spacing $(65.00 \%)$ and seed rate $(64.17 \%)$. The reason for this result could be because of high cost and difficulty in procurement of FYM, lack of knowledge, unwillingness and ignorance of the farmers towards the adoption of improved production technology.

Table 2 revealed that majority $(61.67 \%)$ of the respondents belonged to medium category of technological gap followed by low level of technological gap (21.67\%) and 16.67 per cent with high level of technological gap. This indicates that majority of the farmers falls under the partial and full gap category in adoption of the recommended package and practices, the probable reason might be due to their lack of knowledge and information regarding the recommended turmeric cultivation practices or it might also be because of the unwillingness and reluctance of the farmers to adopt the recommended practices as turmeric is organically grown by tradition (Aglawe et al., 2014).

\section{Correlation co-efficient between selected characteristics and technological gap of turmeric production technology}

The collected data were tabulated and computed to assess the existence of relationship between selected characteristics of the famers and composite technological gap. From the data in Table 3, it is evident that education, extension contact, economic motivation and innovation proneness were negatively and significantly correlated with 
the composite technological gap of the farmers at 0.01 level of significance. Technological gap was found to be lesser with increase in level of education of the farmers. This result might be due to the fact that illiterate farmers or farmers with low education cannot understand new technology as quickly and easily as those farmers with higher level of education who are more susceptible to farm information which give them more scope to augment their knowledge and skills (Dipak, 2012).

An increase in extension contact and economic motivation was also found to encourage farmers to adopt modern agricultural technology to a greater extent which ultimately reduces their technological gap (Kadam2016). It was also observed that technological gap in adoption of turmeric production technology reduces with increase in innovation proneness of the farmers (Markana et al., 2016).

Further, characteristics like annual income, mass media exposure and risk orientation of the farmers were negatively and significantly correlated with the extent of technological gap of the farmers at 0.05 level of significance. This association implies that as annual income of the farmers increases the technological gap decreases.

The probable reason might be that increase in annual income of the farmer helps in optimum and timely procurement of inputs, enable proper use of information sources and enhance the farmer's ability to bear risk and loss incurred in adoption of recommended practices (Prakash 2018).

Mass media exposure was also found to be negatively correlated with technological gap. This implies that the higher the mass media exposure of the farmers the lesser will be their technological gap (Jadhav 2009). There was negative and significant relation between risk orientation and technological gap of the farmers. The possible reason could be that the farmers who are more prone to take risk were able to get maximum returns which thereby influenced their adoption of recommended production technology (Prakash, 2014).

Other characteristics like age, land holding and farming experience were found to be nonsignificant with technological gap of the farmers. This indicates that age, land holding and farming experience has no influence on the extent of technological gap in adoption of recommended turmeric production technology by the farmers (Rajashekhar, 2009).

\section{Multiple regression}

The findings for regression analysis to assess the contribution of all the ten selected independent variables to the dependent variable of i.e. technological gap in turmeric production technology are presented in Table 4.

It was observed that out of the ten variables fitted in the multiple regression analysis, four variables namely, education, extension contact, economic motivation and innovation proneness contributed negatively and significantly to the prediction of technological gap of the respondents and they may be termed as good predictors of technological gap.

The $R^{2}$ value (0.762) suggested that all the variables jointly contributed 76.20 per cent towards variation in the technological gap of the turmeric production technology. This indicated the significant effectiveness of the independent variables in predicting the extent of technological gap of the respondents when all the variables are functioning jointly. This inference was found to be in agreement with Kamble (2016) and Markana et al., (2016). 
Table.1 Distribution of respondents based on their technological gap in recommended turmeric production technology

\begin{tabular}{|c|c|c|c|c|}
\hline \multirow{3}{*}{ Sl. No } & \multirow{3}{*}{ Package of practices } & \multicolumn{3}{|c|}{ Extent of technological gap } \\
\hline & & Full gap & Partial gap & Nil gap \\
\hline & & Frequency & Frequency & Frequency \\
\hline 1. & Recommended varieties & - & $12(10.00)$ & $108(90.00)$ \\
\hline 2. & Seed rate & - & $77(64.17)$ & $43(35.83)$ \\
\hline 3. & Seed treatment & $59(49.17)$ & $20(16.67)$ & $41(34.17)$ \\
\hline 4. & Propagation & - & $50(41.67)$ & $70(58.33)$ \\
\hline 5. & Planting time & - & - & $120(100)$ \\
\hline 6. & Field preparation & - & $56(46.67)$ & $64(53.33)$ \\
\hline 7. & Spacing & - & $78(65.00)$ & $42(35.00)$ \\
\hline 8. & Method of planting & - & $62(51.67)$ & $58(48.33)$ \\
\hline 9. & Application of FYM & - & $94(78.33)$ & $26(21.67)$ \\
\hline 10. & Application of fertilizers & $80(66.67)$ & $16(13.33)$ & $24(20.00)$ \\
\hline 11. & Time of application of FYM/ fertilizers & - & $58(48.33)$ & $62(51.67)$ \\
\hline 12. & Intercrop & - & $52(43.33)$ & $68(56.67)$ \\
\hline 13. & Intercultural operations & - & $47(39.17)$ & $73(60.83)$ \\
\hline 14. & Processing & - & $95(79.17)$ & $25(20.83)$ \\
\hline 15. & Management practices for pest & $79(65.83)$ & $20(16.67)$ & $21(17.50)$ \\
\hline 16. & Management practices for diseases & $107(89.17)$ & $13(10.83)$ & - \\
\hline 17. & Harvesting & - & - & $120(100)$ \\
\hline 18. & Seed storage & - & $24(20.00)$ & $96(80.00)$ \\
\hline
\end{tabular}

Note: Figure in parentheses denotes the percentage to the respective total.

Table.2 Distribution of respondents according to their overall technological gap in adoption of recommended turmeric production technology

\begin{tabular}{|c|l|c|c|}
\hline \multicolumn{4}{|c|}{ Respondents } \\
\hline SI. No. & \multicolumn{1}{|c|}{ Category } & Frequency & Percentage \\
\hline $\mathbf{1 .}$ & Low (Mean - S.D.) & 26 & 21.67 \\
\hline $\mathbf{2 .}$ & Medium (Mean \pm S.D.) & 74 & 61.67 \\
\hline $\mathbf{3 .}$ & High (Mean + S.D.) & 20 & 16.67 \\
\hline & Total & 120 & 100 \\
\hline
\end{tabular}


Table.3 Correlation co-efficient between selected profile characteristics and technological gap of turmeric growers

\begin{tabular}{|c|l|c|}
\hline Sl. No & Independent variables & Correlation coefficient "r" \\
\hline $\mathbf{1 .}$ & Age & $0.115^{\text {NS }}$ \\
\hline $\mathbf{2 .}$ & Education & $-0.665^{* *}$ \\
\hline $\mathbf{3 .}$ & Land holding & $-0.065^{\text {NS }}$ \\
\hline $\mathbf{4 .}$ & Farming experience & $0.096^{\text {NS }}$ \\
\hline $\mathbf{5 .}$ & Annual income & $-0.217^{*}$ \\
\hline $\mathbf{6 .}$ & Extension contact & $-0.808^{* *}$ \\
\hline $\mathbf{7 .}$ & Mass media exposure & $-0.210^{*}$ \\
\hline $\mathbf{8 .}$ & Economic motivation & $-0.679^{* *}$ \\
\hline $\mathbf{9 .}$ & Innovation proneness & $-0.610^{* *}$ \\
\hline $\mathbf{1 0 .}$ & Risk orientation & $-0.211^{*}$ \\
\hline
\end{tabular}

** Significant at 0.01 level of probability, ${ }^{*}$ Significant at 0.05 level of probability

Table.4 Regression analysis of technological gap of turmeric production technology with independent variables

\begin{tabular}{|l|l|c|c|c|c|}
\hline Sl. No & Independent variables & Beta & $\begin{array}{c}\text { Regression } \\
\text { Co-efficient } \\
\left(\mathbf{b}_{\mathbf{1}}\right)\end{array}$ & $\begin{array}{c}\text { Standard error } \\
\text { (S.E.) }\end{array}$ & $\begin{array}{c}\text { 't' value } \\
\text { of 'b' }\end{array}$ \\
\hline $\mathbf{1 .}$ & Age & -0.059 & -0.066 & 0.090 & -0.728 \\
\hline $\mathbf{2 .}$ & Education & -0.200 & -1.674 & 0.554 & $-3.022^{* *}$ \\
\hline $\mathbf{3 .}$ & Land holding & 0.024 & 0.172 & 0.772 & 0.223 \\
\hline $\mathbf{4 .}$ & Farming experience & 0.058 & 0.067 & 0.094 & 0.713 \\
\hline $\mathbf{5 .}$ & Annual income & -0.093 & -0.073 & 0.081 & -0.896 \\
\hline $\mathbf{6 .}$ & Extension contact & -0.512 & -2.189 & 0.298 & $-7.355^{* *}$ \\
\hline $\mathbf{7 .}$ & Mass media exposure & -0.041 & -0.165 & 0.195 & -0.847 \\
\hline $\mathbf{8 .}$ & Economic motivation & -0.153 & -0.766 & 0.367 & $-2.088^{*}$ \\
\hline $\mathbf{9 .}$ & Innovation proneness & -0.171 & -0.379 & 0.137 & $-2.756^{* *}$ \\
\hline $\mathbf{1 0 .}$ & Risk orientation & 0.091 & 0.478 & 0.282 & 1.693 \\
\hline
\end{tabular}

** Significant at 0.01 level of probability,

* Significant at 0.05 level of probability

$R^{2}=0.762$

$\mathrm{F}=34.977$

It can be concluded that, majority of the respondents belonged to medium level of technological gap followed by low level and high level technological gap category. It was also found that out of ten independent variables, seven variables viz., education, annual income, extension contact, mass media exposure, economic motivation, innovation proneness and risk orientation showed negative and significant relationship with composite technological gap. Among the ten variables, four variables viz., education, extension contact, economic motivation and innovation proneness were important variables affecting the technological gap, respectively. 


\section{Acknowledgement}

The authors acknowledge the contributions of Phidalangki Lyngdoh, M. Kunjaraj Singh, Daya Ramand N. Gopimohan Singh, College of Agriculture, Central Agricultural University, Imphal, Manipur (India) for their technical support and valuable contributions to the manuscript.

\section{References}

Aglawe, D.D., Kokate, D.S. and Lairenlakpam, M. (2014). Technological gap in adoption of recommended turmeric production technology among turmeric growers. Guj. J. Ext. Edu. 25(1):88.

Dipak. A.D., (2012). Technological gap in turmeric production technology. (Doctoral dissertation, Mahatma Phule Krishi Vidyapeeth, Rahuri).

Jadhav, B.A. (2009). Technological gap in adoption of recommended practices of mango cultivation. M. Sc. (Agri) Thesis, Univ. Agric. Sci., Dharwad, India.

Kadam, Y.A., (2016). Technological gap in ginger production technology (Doctoral dissertation, Vasantrao Naik
Marathwada Krishi Vidyapeeth, Parbhani).

Kamble, V.B., (2016). Technological gap of recommended management practices by the okra growers (Doctoral dissertation, Vasantrao Naik Marathwada Krishi Vidyapeeth, Parbhani).

Kulkarni, N.P., (2014). An analysis of technological gap and entrepreneurial behaviour of rose cultivators. M. Sc.(Agri.) Thesis, Univ. Agric. Sci., Dharwad.

Markana. J.G., Kalsariya. B.N., Jadeja. M. K., Patel. J.V. and Marviya. P.B. (2016). Technological gap in adoption of improved cultivation practices by Kharif groundnut growers. International Journal of Agriculture Sciences. 8(27):1583-1585.

Prakash. P.P., (2014). Technological gap in turmeric production technology in Sangli district. (Doctoral dissertation Mahatma Phule Krishi Vidyapeeth, Rahuri).

Uikey. G., Gurjar. R. S. and Patel. Mm. (2018). Analysis of technological gap in potato production technology. Journal of Pharmacognosy and Phytochemistry. SP1: 2428-2432.

\section{How to cite this article:}

Phidalangki Lyngdoh, M. Kunjaraj Singh, Daya Ram and Gopimohan Singh, N. 2019. Correlates of Technological Gap in Turmeric Production Technology by the Farmers of West Jaintia Hills District, Meghalaya, India. Int.J.Curr.Microbiol.App.Sci. 8(05): 2141-2146. doi: https://doi.org/10.20546/ijcmas.2019.805.251 